\title{
Basic Website Creation Training for Muhammadiyah Mamala High School Students in Central Maluku Regency
}

\author{
Citra Fathia Palembang ${ }^{1 *}$, Mozart Winston Talakua ${ }^{2}$, Zeth Arthur Leleury ${ }^{3}$, Yopi Andry \\ Lesnussa $^{4}$, Francis Yunito Rumlawang ${ }^{5}$, Jefri Esna Thomas Radjabaycolle ${ }^{6}$, Abraham \\ Zakharia Wattimena ${ }^{7}$, Henry Willyam M. Patty ${ }^{8}$ \\ $1^{\star}, 2,3,4,5,6,7,8$ Faculty of Math and Science, University of Pattimura Ambon \\ citra.palembang@fmipa.unpatti.ac.id ${ }^{\left.1^{*}\right)}$
}

\begin{abstract}
Abstrak
Pelaksanaan kegiatan PkM oleh tim memberikan materi dan pelatihan kepada Siswa SMA Muhammadiyah Mamala bagaimana membangun sebuah website dengan mudah dari dasar menggunakan Content Management System (CMS) sampai website berhasil diunggah ke Internet (Hosting) baik secara gratis maupun berbayar. Tujuan dari kegiatan PkM ini siswa memperoleh pengetahuan teknologi informasi tidak hanya sebatas dapat mengakses informasi saja, akan tetapi memiliki kecakapan dalam menciptakan wadah/media informasi berupa website dan diharapkan kedepannya dapat membantu pihak sekolah dalam mengembangkan website sekolah.
\end{abstract}

Kata kunci: Website, Sekolah, Informasi

\begin{abstract}
The team's implementation of community service activities provides materials and training to Muhammadiyah Mamala High School students on how to easily build a website from the ground up using a content management system (CMS) until the website is successfully uploaded to the Internet (hosting), both for free and for a fee. The goal of this community service activity is for students to gain information technology knowledge that is not limited to being able to access information, but also to being able to create a container/information medium in the form of a website and, hopefully, to help the school in developing the school website in the future.
\end{abstract}

Keywords : Website, School, Information

\section{Introduction}

The mastery of science and technology plays a very important role at the beginning of the industrial revolution era 4.0, especially for students who sit in school, from elementary school to university level. With the demands of information technology mastery needs in various aspects of life today, the use of information technology for high school students or equivalent has become important to be applied and implemented

The demands of information technology mastery are characterized by schools' competing to install internet networks so that students can benefit from the ease of accessing information via the internet. Educators, students, and the general public will refer to a website that is known for providing accurate information. However, mastery of information technology is not limited to being able to access information; the ability to 
create a container/information medium in the form of a website is also increasing, albeit with various criteria in its creation.

A website for schools is a very important requirement, there are many benefits that can be obtained from having a school website, including: a very effective school promotion tool and can be widely achieved by displaying all forms of achievements that have been achieved and school facilities in supporting the learning process -teaching, improving the quality of education to the community in a more primal manner (Anwar et al., 2017), and being able to present information anytime, accessible from anywhere by anyone with an internet connection without having to go to school to get the latest information.

A school website is an absolute necessity. There are numerous advantages to having a school website, including the following: being a very effective and widely accessible means of school promotion by displaying all forms of achievements that have been achieved and providing school facilities in support of the teaching-learning process, improving the quality of education in the community in a better manner (Anwar et al., 2017), and the ability to present information at any time. Anyone with an internet connection can access it from anywhere and get the most up-to-date information without having to go to school.

Muhammadiyah Mamala High School is a high school in Central Maluku Regency with limited availability of educators and education in the field of information technology, resulting in students lacking knowledge of information technology. Muhammadiyah Mamala High School also lacks a school website as a source of school information. From these problems, the Faculty of Mathematics and Natural Sciences' Community Service team provides material on the development of information technology in the current era of information technology in Indonesia to provide training on how to build a website easily from the basis of using a CMS, in this case, WordPress, and how to upload to the internet (hosting) both for free and paid so that Muhammadiyah Mamala High School students can learn about information technology.

\section{Implementation Method}

This activity is carried out using a personal approach method, namely to hone the skills of Muhammadiyah Mamala High School students in Central Maluku Regency in utilizing offline information technology, providing direct guidance to students ranging from the installation of required devices to the process of uploading websites built offline to free hosting providers.

\section{Result and Discussion}

This community service activity consists of providing basic website creation training to Muhammadiyah Mamala High School students in Central Maluku Regency. Before beginning the basic website creation training activities, the team pre-tested students to determine the depth of the students' abilities regarding the website, after that the website creation training was carried out, and the training was concluded with an evaluation of the training activities that had been carried out in the form of Post Tests. This activity took place on Saturday, October 30, 2021, at the computer laboratory of Muhammadiyah Mamala High School in Central Maluku Regency, and was attended by 20 third-grade students. 
Because the headmaster of Muhammadiyah High School in Central Maluku Regency was not there, the activity began with a speech by one of the teachers who represented him. The training material is then delivered by eight instructors in four (4) sessions.

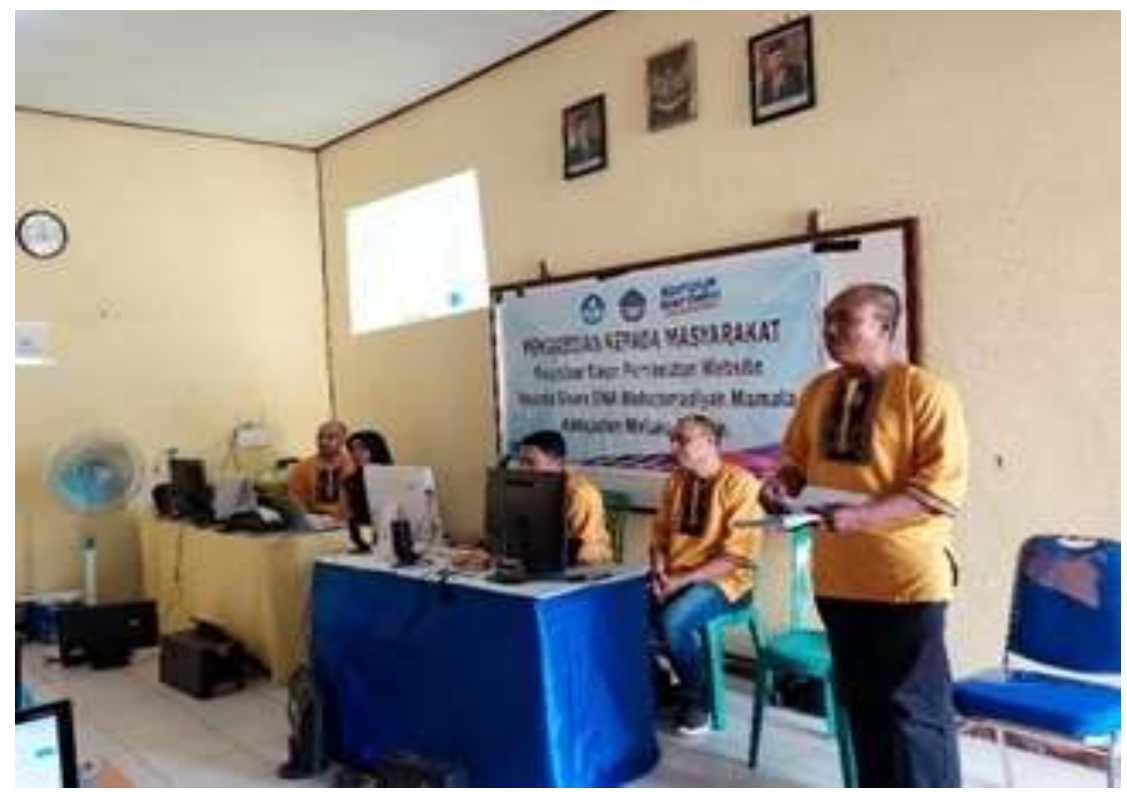

Figure 1. Instruction from Lecturer of the Faculty of Mathematics and Natural Sciences Pattimura University for the filling of Pre-Test and Post-Test to Students.

The participants were introduced to the website introduction material during the first session. Then, after a pre-test to assess students' knowledge of the website, the provision of a short material website introduction, the installation of application needs used, and the entry into basic training sessions of website creation, including; local installation of servers on their respective computers, WordPress installation, how to connect with databases, set the website layout, fill in the content of the installation.

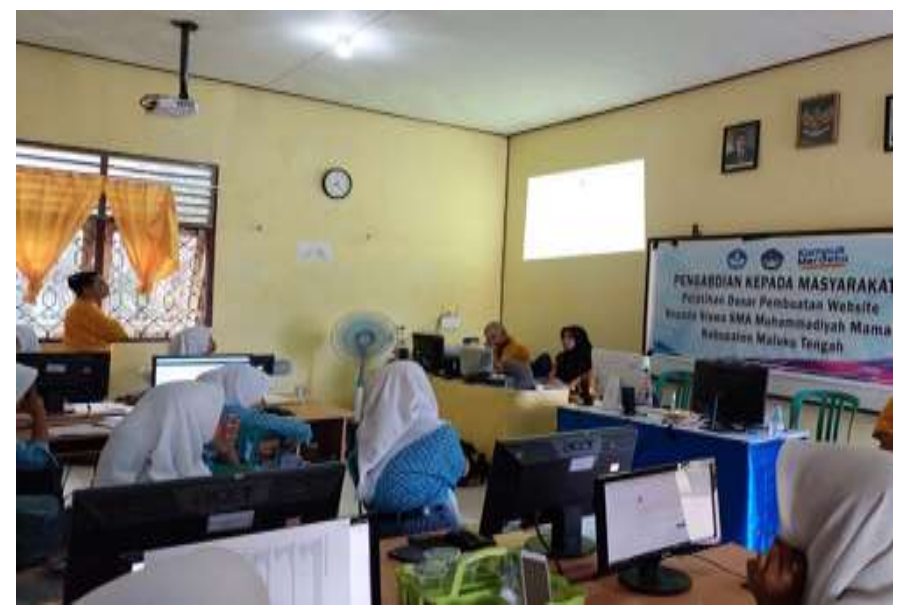

Figure 2. Submission of Material by a Lecturer from Pattimura University's Faculty of Mathematics and Natural Sciences. 
In this activity, we completed the delivery of materials in the form of modules and offered assistance in the creation of school websites that did not already exist.

\section{Conclusion}

Based on the implementation of activities, it can be concluded that Muhammadiyah Mamala High School students understand information technology in the 4.0 era and how to create a website from the ground up and upload it to the internet based on the pre-test and post-test processes after the activity is completed.

Students can create a personal blog to express their writing creativity, as seen by monitoring teammates during the training process on each student's computer, so that students can develop a website that is more dynamic than what will be learned in the future from website creation training.

\section{References}

Anwar, F., Yunianto, M., Purnomo, A., Hartono, R. Upaya Peningkatan Kualitas Sekolah Melalui Pembuatan Dan Pengelolaan Website Sekolah, Wasana Nyata. Jurnal Pengabdian Kepada Masyarakat. Vol.1 No.3, Oktober 2017. 